\title{
Remote Sensing Application to Estimate Groundwater Recharge in Denpasar and Surrounding Areas
}

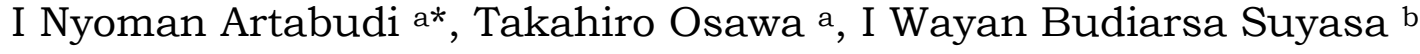 \\ a Center for Remote Sensing and Ocean Science (CReSOS), Udayana University, PB Sudirman Street, Post \\ Graduate Building, Denpasar, Bali 80232, Indonesia \\ ${ }^{b}$ Graduate School of Environmental Sciences, Udayana University, PB Sudirman Street, Post Graduate Building, \\ Denpasar, Bali 80232, Indonesia \\ * Correspondence: n.artabudi@yahoo.com
}

Received: 14 June 2016; Accepted: 31 January 2017; Available online: 4 February 2017

\begin{abstract}
Water is one of the most important resources for human life, both to support the daily activities and for irrigation purposes as well as supporting tourism industry. Until now the groundwater is still ranked as the major needs, especially in densely populated areas like Denpasar. Groundwater is renewable natural resources, and plays an important role in the provision of water supplies for various purposes. Understanding the spatial variability of groundwater recharge is very important for proper water resource management. Precipitation measurement by satellite especially Global Satellite Mapping for Precipitation, can be applied to large areas only, it can be stated that use of satellite data always results in an improvement of the spatial precipitation estimate if gauge density is low. The aim of this research was to determine precipitation patterns, precipitation groundwater relationship and to estimate local groundwater recharge rate across the Southern Bali basin using remote sensing. This study considers the direct estimation of recharge using recovery of the groundwater level $(\Delta \mathrm{H})$ and total precipitation $(\mathrm{Pt})$ during the wet period. Groundwater recharge was estimated from these two variables using a simple regression equation. The patterns of precipitation in research area was monsoonal dry season occurred in July to August, wet season occurs during November to April and punctuated by transitional season. Precipitation influence on groundwater oscillation occurred on 1 2 months earlier. The amount of recharge rate in the study area based on the results of the study period 2005 2009, for the precipitation data from Global Satellite Mapping for Precipitation ranges from $218 \sim 220 \mathrm{~mm}$ per year or about 26 percent of the annual average of precipitation and $650 \sim 660 \mathrm{~mm}$ per year or about 32 percent based on the rain gauge data.
\end{abstract}

Keywords: precipitation; groundwater; satellite; recharge

\section{Introduction}

Water is one of the most important resources for human life, both to support the daily activities as well as for irrigation purposes and tourism industry. Until now the groundwater is still ranked as a major need, especially in densely populated areas like in Denpasar.

Some place and near around it where there is no river or a large lake with adequate water quality like Denpasar city, almost water supply needs are met from groundwater, and recharge is having a very important role in maintaining the availability and quality of groundwater. Information about groundwater recharge in Denpasar and surrounding areas is still very limited, so it is necessary to do research about groundwater recharge.

Developments in satellite hydrology make it possible to evaluate the actual water use of various land covers and when matched with spatial precipitation patterns, partly derived by remote sensing, allow identification of patterns of groundwater recharge and discharge. 
Despite the relatively low accuracy of daily precipitation measurement by satellite, and applied to large areas only, it can be stated that use of satellite data always results in an improvement of the spatial precipitation estimate if gauge density is low (Meijerink, 1996).

Groundwater exploitation should not exceed the recharge rate of the corresponding groundwater basin, which depends on many factors, including soil, topography, vegetation, and climate. Therefore, even in the same aquifer, various combinations of factors can cause different groundwater hydrographs. Consequently, understanding the spatial variability of groundwater recharge is very important for proper water resource management that leads to sustainable development and preservation of groundwater resources (Moon et al., 2004).

Based on these issues needs to do research, as for the purpose of this study: (1) to determine the precipitation patterns over five years period 2005 to 2009 using satellite microwave datasets and rain gauge data; (2) to calculate the correlation between groundwater and precipitation using GSMaP and rain gauge data; and (3) to determine the rate value of groundwater recharge.

\section{Materials and Methods}

Research area is located in Denpasar and surrounding area and situated at a height of $0 \sim 1717$ meters above sea level. The coordinate position is $8^{\circ} 14^{\prime} \sigma^{\prime \prime} \sim 8^{\circ} 47^{\prime} 13.2^{\prime \prime}$ South Latitude and $115^{\circ} 0^{\prime} 0$ " $115^{\circ} 23^{\prime} 27.6^{\prime \prime}$ East Longitude (Figure 1).

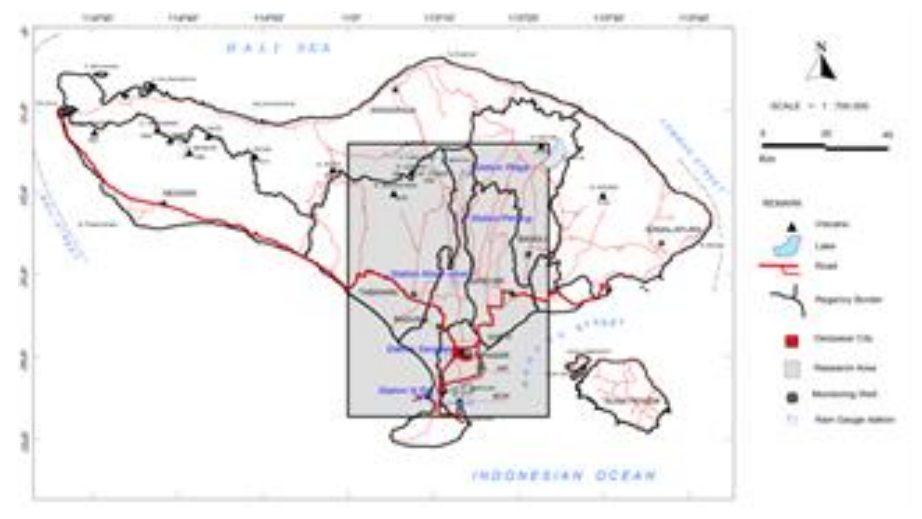

Figure 1. Research location

Research Material are GSMaP (Global Satellite Mapping for Precipitation) satellite datasets period 2005 - 2009, in situ data from well hydrograph and monthly precipitation derived from rain gauge measurement station with the same period. Data analysis conducted on precipitation data from GSMaP, rain gauge data and groundwater level fluctuation, arranged in a table. Then do the analysis with a simple linear regression method.

Degallier (1966), showed a method used for water recharge is that the component forming a ground water hydrograph, including those from a groundwater system, frequently each had a recession that could be approximated by simple exponential relationships of the from (Figure 2).

where $h_{0}$ and $h$ are the water level above discharge level at the beginning of the measurement period and after a certain time $(t)$ respectively and $a$ is known as coefficient of recession or discharge coefficient.

According to Korkmaz (1998), the exponential formula, on a semilogarithmic paper when water level is plotted to the log scale and time to the arithmetic scale, the recession curves plot as nearly as straight lines (Figure 3). In the logarithm with base 10, the formula is as follows derived from equation (1). 
The recovery of the water level $\Delta \mathrm{H}$, under natural hydrological conditions is a mirror image of the recession curve. The recovery of the water level varies from year to year, depending on the amount of total precipitation ( $\mathrm{Pt}$ ) in wet period (Figures 2 and 3).

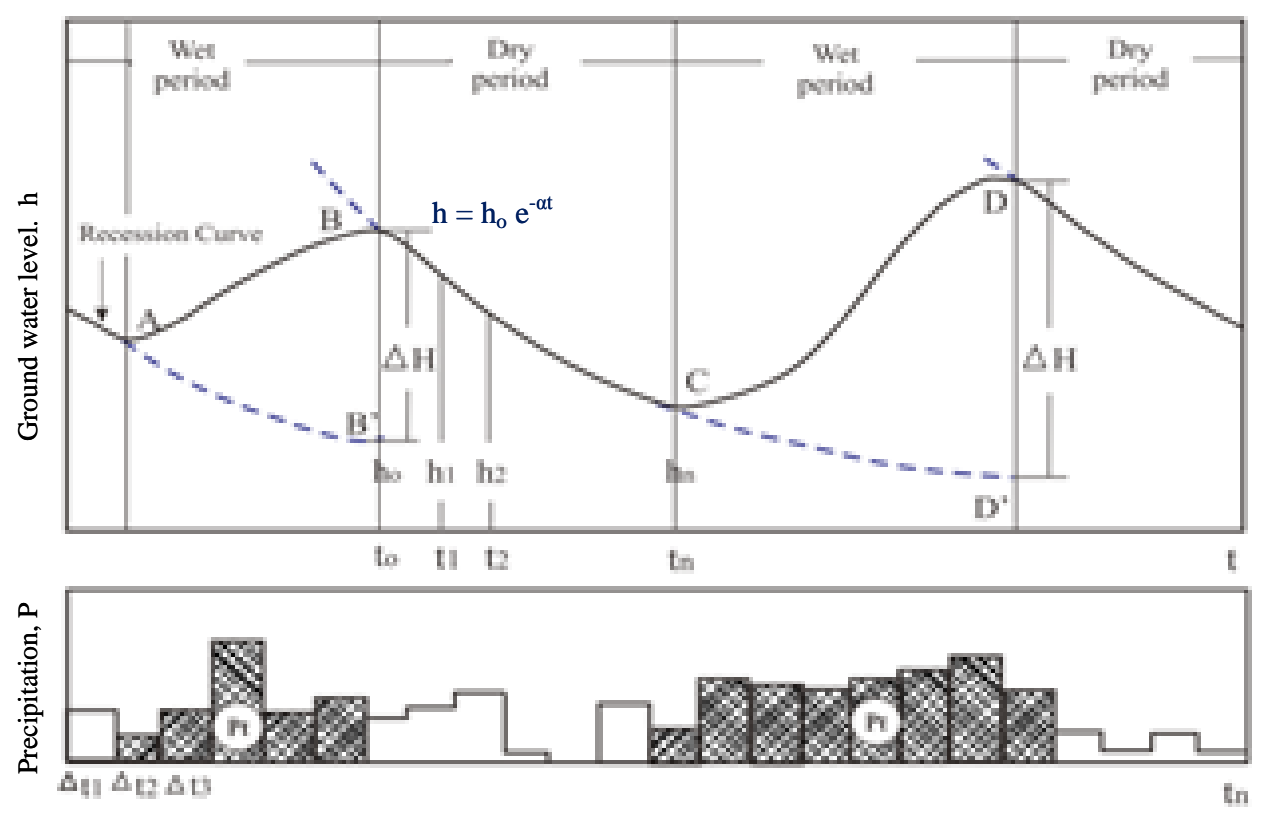

Figure 2. Fluctuation in water levels caused by recharge from Precipitation (Degallier, 1966)

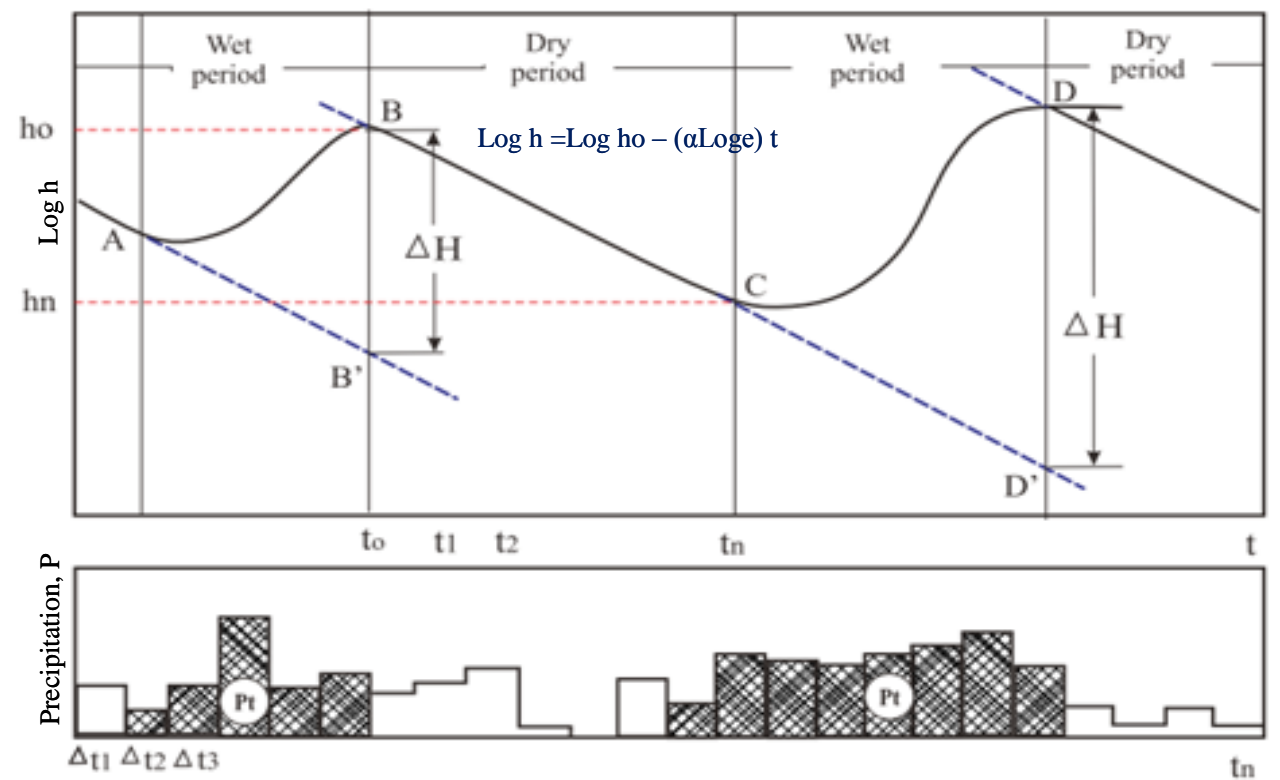

Figure 3. Fluctuation in water levels caused by recharge from Precipitation (Korkmaz, 1998)

The degree of correlation between fluctuations of groundwater level and fluctuation of total precipitation $(\mathrm{Pt})$ in wet period furnishes a clue as to the freeness of the connection between recharge and total precipitation (Pt) in wet period (Korkmaz, 1998).

This study considers the direct estimation of recharge using recovery of the groundwater level $(\Delta \mathrm{H})$ and total precipitation $(\mathrm{Pt})$ during wet period. Groundwater recharge is estimated from these two variables using a simple regression equation as bellow: 
where $\Delta \mathrm{H}$ is recovery of groundwater level, $\mathrm{Pt}$ is total precipitation during the wet period, a and $\mathrm{b}$ are the coefficients.

Precipitation intercept, $\mathrm{Pe}$ is intersection of the total precipitation recovery straight line with zero-total precipitation axis and it represents the amount of surface run off and evapotranspiration for the same period. Recovery or recharge from precipitation is a function of the amount of total precipitation (Pt). If the intercept is $\mathrm{Pe}$, the recharge $(\mathrm{Ps})$ is estimated as:

\section{Results and Discussions}

Precipitation Patterns Period from 2005 to 2009 in research area, Based on data from rain gauge average ranging $1.40 \sim 566.36 \mathrm{~mm} /$ month and monthly average is 172.1 $\mathrm{mm} /$ month. Wet months from November to April, while dry falls from July to August. It is punctuate by transition season. GSMaP data is different in number ranged between 0.01 $\sim 333.90 \mathrm{~mm} /$ month and $70 \mathrm{~mm} /$ month in the average that is about 41 percent of rain gauge. GSMaP data showed same patterns and statistically has a very good agreement with the ground reference data (Figure 4).

Monthly Precipitation Average (2005-2009)

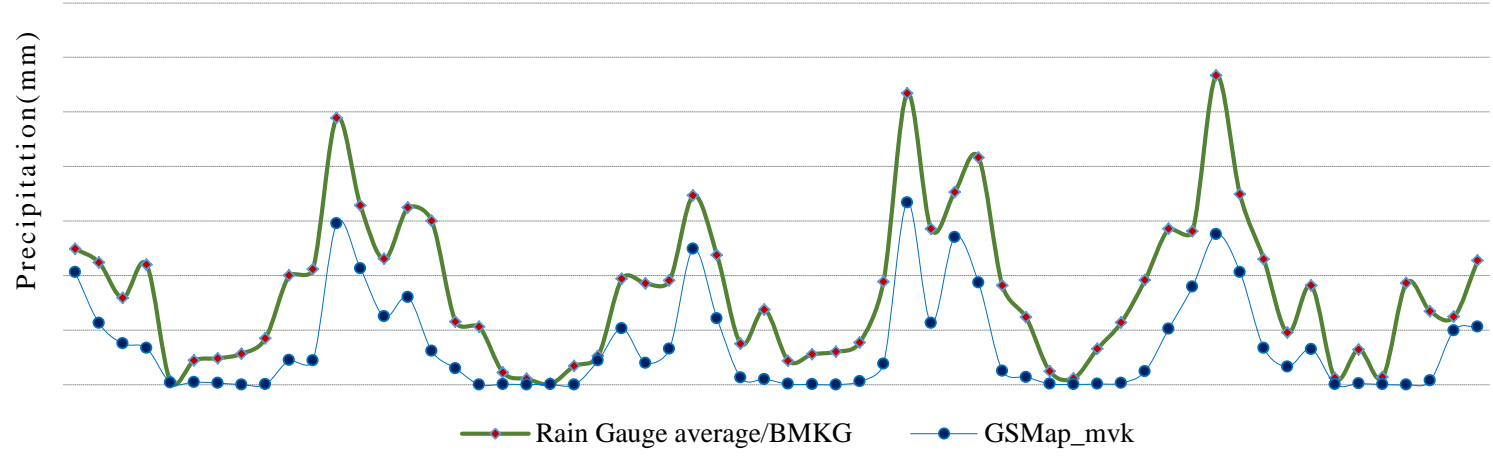

Figure 4. Time series monthly precipitation measured by rain gauge station and GSMaP in research area

The time series during period 2005 2009 precipitation patterns are similar and has a strong correlation between rain gauge and GSMaP data the coefficient of determination is about 0.82 .

Groundwater recharge event due to the precipitation that occurs 1 2 months earlier give the high correlation with groundwater level changes. The coefficient of correlation = $0.71 \sim 0.77$ this is mean that precipitation takes between $1 \sim 2$ months to recharge the groundwater.

Aquifers that exposed in the area of research is dominated by Buyan Beratan and Batur volcanic roks composed mostly of lava and fuff, earlier quarternary age, and other aquifer is known from drilling log data, the Palasari formation which consists of conglomerate rock unit, sandstone and reef limestone age of this formation is Pliocene or Upper Tertiary (Figure 5).

Precipitation data from rain gauge station and groundwater level fluctuation from three monitoring wells that is Bima cottages, Werdapura and GOR Ngurah Rai observation well were analyzed. The recovery $(\Delta \mathrm{H})$ analyzed by plotting data obtained from the hydrograph into semilogarithmic 10 base graph, and then analyzed by a simple linear regression, for example, the calculation and analysis here is using Werdapura observation well data and the results are presented in Figure 6. 


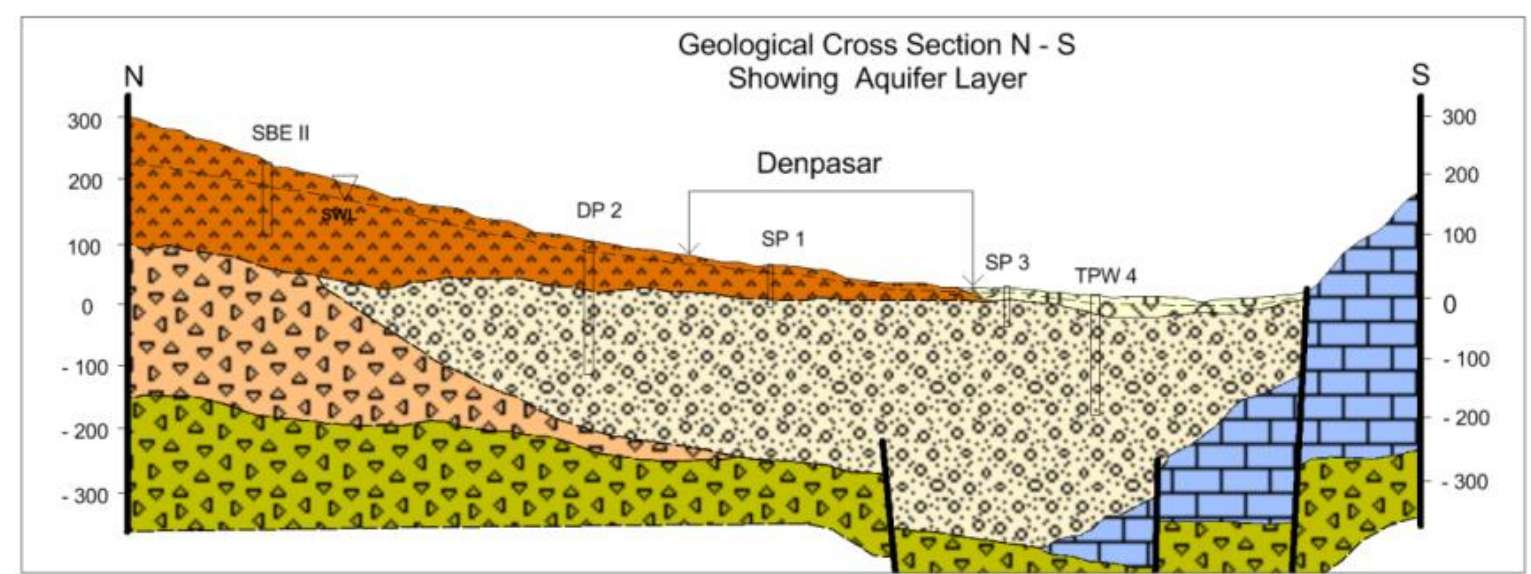

Legend :

\begin{tabular}{|c|c|c|c|}
\hline \multirow[t]{2}{*}{ 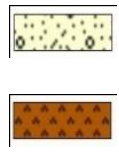 } & Alluvium & $\therefore \square$ & JembranaVolcanics \\
\hline & $\begin{array}{l}\text { Buyan-Beratan Group and Batur } \\
\text { Volcanics }\end{array}$ & 垔 & Selatan Formation \\
\hline $8 \times \%$ & Palasari Formation & 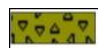 & Ulakan Formation \\
\hline
\end{tabular}

Figure 5. Geological cross section North - South showing the aquifer layer in the study area (Hadiwidjojo et al., 1998)
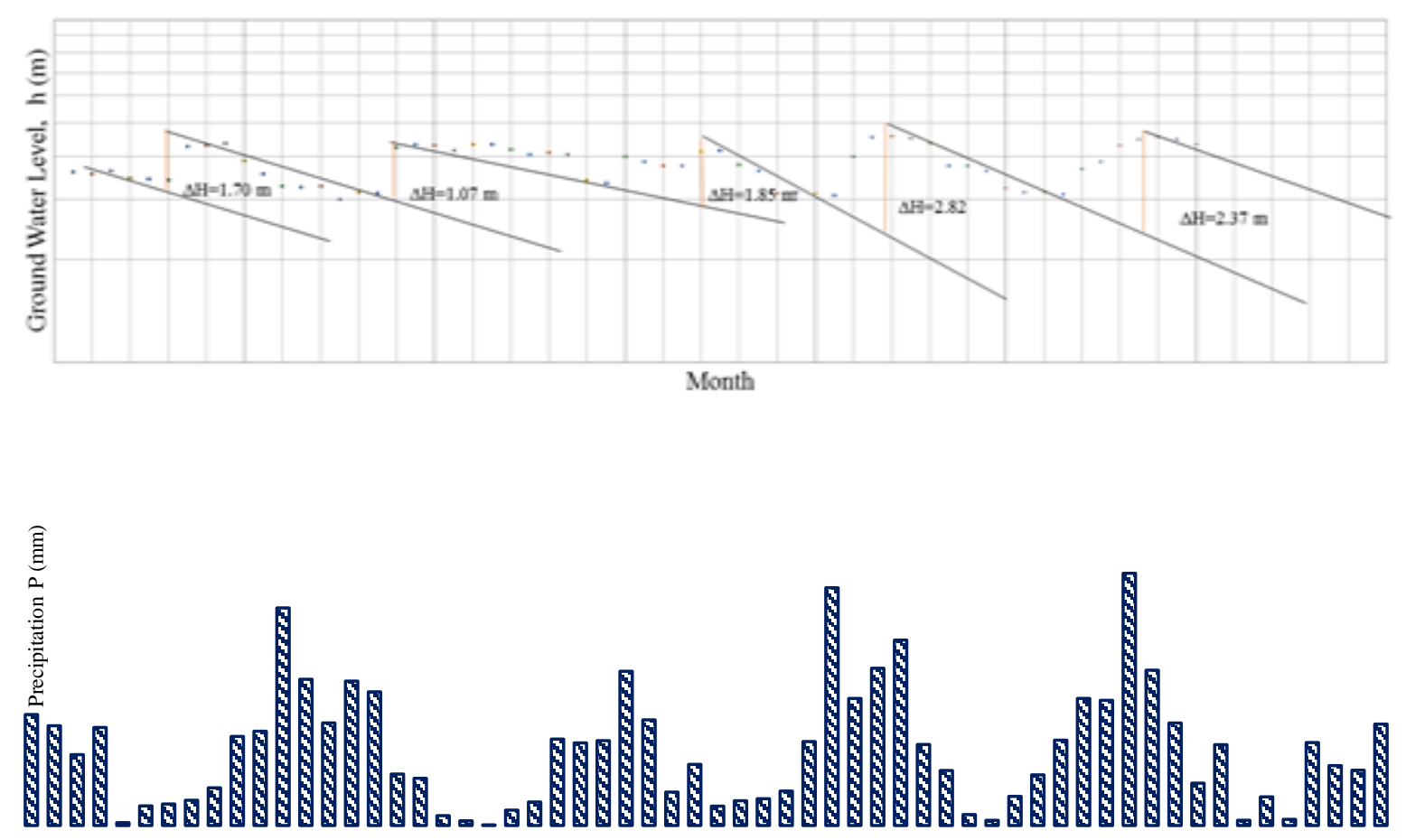

Figure 6. Fluctuation of groundwater levels (top) caused by recharge from precipitation (rain gauge; bottom) in Werdapura Observation Well

In a similar way to the Bima Cottages and GOR Ngurah Rai observation wells, the plotting results of recovery $(\Delta \mathrm{H})$ obtained as Table 1 .

Table 1. The recovery as result of plotting groundwater level data to semilogarithmic paper 


\begin{tabular}{cccccc}
\hline Year & 2005 & 2006 & 2007 & 2008 & 2009 \\
\hline Bima Cottages $(\Delta \mathrm{H}) \mathrm{m}$ & 1.75 & 1.05 & 1.84 & 2.85 & 2.35 \\
Werdapura $(\Delta \mathrm{H}) \mathrm{m}$ & 1.72 & 1.07 & 1.85 & 2.82 & 2.37 \\
GOR Ngurah Rai $(\Delta \mathrm{H}) \mathrm{m}$ & 1.74 & 1.08 & 1.86 & 2.83 & 2.38 \\
\hline
\end{tabular}

Table 2. The result of linier regression analysis from rain gauge data

\begin{tabular}{lcccccc}
\hline Type of relation & $\begin{array}{c}\text { Number } \\
\text { of obser- } \\
\text { vation }\end{array}$ & $\begin{array}{c}\text { Coefficient of } \\
\text { determination } \\
\left(\mathrm{r}^{2}\right)\end{array}$ & $\begin{array}{c}\text { Standard } \\
\text { error of } \\
\text { estimated }\end{array}$ & $\begin{array}{c}\text { Computed } \\
\text { F value }\end{array}$ & $\begin{array}{c}\text { Signifi- } \\
\text { cance F }\end{array}$ & Regression equation \\
\hline $\begin{array}{l}\text { Precipitation } \\
\text { recovery relation, }\end{array}$ & 5 & 0.967 & 0.142 & 88.212 & 0.003 & $\Delta \mathrm{H}=-2.680+0.003 \mathrm{Pt}$ \\
$\begin{array}{l}\text { Bimacottages } \\
\text { Total Precipitation } \\
\text { recovery relation, }\end{array}$ & 5 & 0.975 & 0.122 & 115.945 & 0.002 & $\Delta \mathrm{H}=-2.622+0.003 \mathrm{Pt}$ \\
$\begin{array}{l}\text { Werdapura } \\
\text { Total Precipitation } \\
\text { recovery relation, } \\
\text { GOR Ngurah Rai }\end{array}$ & 5 & 0.973 & 0.126 & 107.590 & 0.002 & $\Delta \mathrm{H}=-2.599+0.003 \mathrm{Pt}$ \\
\hline
\end{tabular}

Based on the recovery obtained from semilogarithmic 10 base graphic above, the regression equation obtained from the regression analysis. Precipitation intercept $(\mathrm{Pe})$ is intersection of the total precipitation recovery straight line with zero total precipitation axis (Figure 7) it represents the amount of surface run of and evapotranspiration. Then the rate of groundwater recharge can be estimated by using Table 3 . By applying to the same graph, Interception (Pe) for the Bima Cottages observation well obtained $893.33 \mathrm{~mm}$ and GOR Ngurah Rai observation well about $866.33 \mathrm{~mm}$.

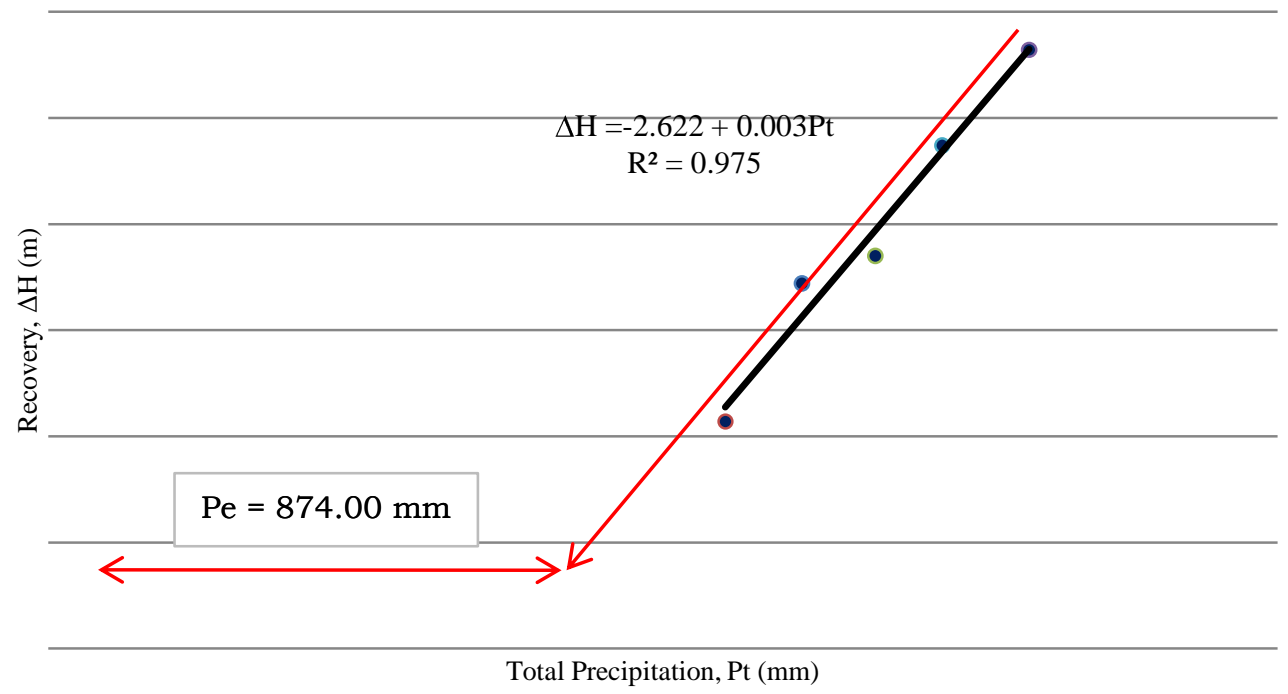

Figure 7. Total precipitation (rain gauge) in wet period - recovery of groundwater level relationship in Werdapura Observation Well

Table 3. Hydrologic characteristic of Werdapura Observation Well based on rain gauge data 


\begin{tabular}{|c|c|c|c|c|}
\hline \multicolumn{3}{|c|}{ Werdapura Observation Well } & \multicolumn{2}{|c|}{$\begin{array}{c}\text { Interception } \\
\mathrm{Pe}=874.00 \mathrm{~mm}\end{array}$} \\
\hline year & $\begin{array}{c}\text { Annual } \\
\text { Precipitation } \\
\mathrm{P}_{\mathrm{y}}(\mathrm{mm}) \\
\end{array}$ & $\begin{array}{c}\text { Computed Total } \\
\text { Precipitation } \\
\mathrm{P}_{\mathrm{t}}=(\Delta \mathrm{H}+\mathrm{a}) / \mathrm{b}(\mathrm{mm})\end{array}$ & $\begin{array}{l}\text { Recovery } \\
\Delta \mathrm{H}(\mathrm{m})\end{array}$ & $\begin{array}{c}\text { Recharge } \\
\mathrm{P}_{\mathrm{s}}(\mathrm{mm}) \\
\left(\mathrm{P}_{\mathrm{s}}=\mathrm{P}_{\mathrm{t}}-\mathrm{P}_{\mathrm{e}}\right) \\
\end{array}$ \\
\hline 2005 & $1,992.92$ & $1,447.33$ & 1.72 & 573.33 \\
\hline 2006 & $1,720.18$ & $1,230.67$ & 1.07 & 356.67 \\
\hline 2007 & $2,130.88$ & $1,490.67$ & 1.85 & 616.67 \\
\hline 2008 & $2,333.88$ & $1,814.00$ & 2.82 & 940.00 \\
\hline 2009 & $2,184.46$ & $1,664.00$ & 2.37 & 790.00 \\
\hline Average & $2,072.46$ & $1,529.33$ & & 655.33 \\
\hline
\end{tabular}

In the same way as Table 3 for the other observation well that are Bima Cottages and GOR Ngurah Rai Observation well, the recharge rate is calculated in the same manner as an example of the analysis. The results are obtained as follows: Bima cotttages Observation well recharge rate average was $656.00 \mathrm{~mm} /$ year, and for the GOR Ngurah Rai observation well recharge rate average was $659.33 \mathrm{~mm} /$ year.

Similarly with the precipitation from rain gauge, the relationship between precipitation of GSMaP data and groundwater level fluctuation from three monitoring wells that is Bima cottages, Werdapura and GOR Ngurah Rai observation well were analyzed. The recovery $(\Delta \mathrm{H})$ also analyzed by plotting data obtained from the hydrograph into semilogarithmic 10 base graph, and the result is the same as shown in Table 1 and then analyzed by a simple linear regression and the result is shown in Table 4.

Table 4. The result of linier regression analysis from GSMaP data

\begin{tabular}{|c|c|c|c|c|c|c|}
\hline Type of relation & $\begin{array}{l}\text { Number } \\
\text { of obser- } \\
\text { vation }\end{array}$ & $\begin{array}{l}\text { Coefficient of } \\
\text { determination } \\
\left(\mathrm{r}^{2}\right)\end{array}$ & $\begin{array}{l}\text { Standard } \\
\text { error of } \\
\text { estimated }\end{array}$ & $\begin{array}{l}\text { Computed } \\
\text { F value }\end{array}$ & $\begin{array}{l}\text { Signifi- } \\
\text { cance F }\end{array}$ & Regression equation \\
\hline $\begin{array}{l}\text { Total Precipitation } \\
\text { recovery relation, } \\
\text { Bima Cottages }\end{array}$ & 5 & 0.942 & 1.88 & 48.544 & 0.006 & $\Delta \mathrm{H}=-4.580+0.009 \mathrm{Pt}$ \\
\hline $\begin{array}{l}\text { Total Precipitation } \\
\text { recovery relation, } \\
\text { Werdapura }\end{array}$ & 5 & 0.926 & 0.209 & 37.535 & 0.009 & $\Delta \mathrm{H}=-4.419+0.009 \mathrm{Pt}$ \\
\hline $\begin{array}{l}\text { Total Precipitation } \\
\text { recovery relation, } \\
\text { GOR Ngurah Rai }\end{array}$ & 5 & 0.928 & 0.206 & 38.482 & 0.008 & $\Delta \mathrm{H}=-4.402+0.009 \mathrm{Pt}$ \\
\hline
\end{tabular}

Based on the recovery obtained from semilogarithmic 10 base graphic above, the regression equation obtained from the regression analysis, and precipitation intercept $(\mathrm{Pe})$ is intersection of the total precipitation recovery straight line with zero total precipitation axis (Figure 8), it represents the amount of surface run of and evapotranspiration. Then the rate of groundwater recharge can be estimated by using Table 5 .

Precipitation intercept $(\mathrm{Pe})$ for the other observation well analyzed in the same manner, namely by plotting a linear regression relationship between total precipitation and recovey. The same as illustrated in the analysis and calculations in Figure 8, so that the results obtained as follows; Bima Cottages observation well obtained $508.89 \mathrm{~mm}$ and GOR Ngurah Rai observation well about $481.11 \mathrm{~mm}$.

The other observation well that are Bima Cottages and GOR Ngurah Rai Observation well, the recharge rate is calculated in the same manner as an example of the analysis (Table 5). The results are obtained as follows: Bima cotttages Observation well recharge rate average was $218.67 \mathrm{~mm} /$ year, and for the GOR Ngurah Rai observation well recharge rate average was $219.78 \mathrm{~mm} /$ year. 


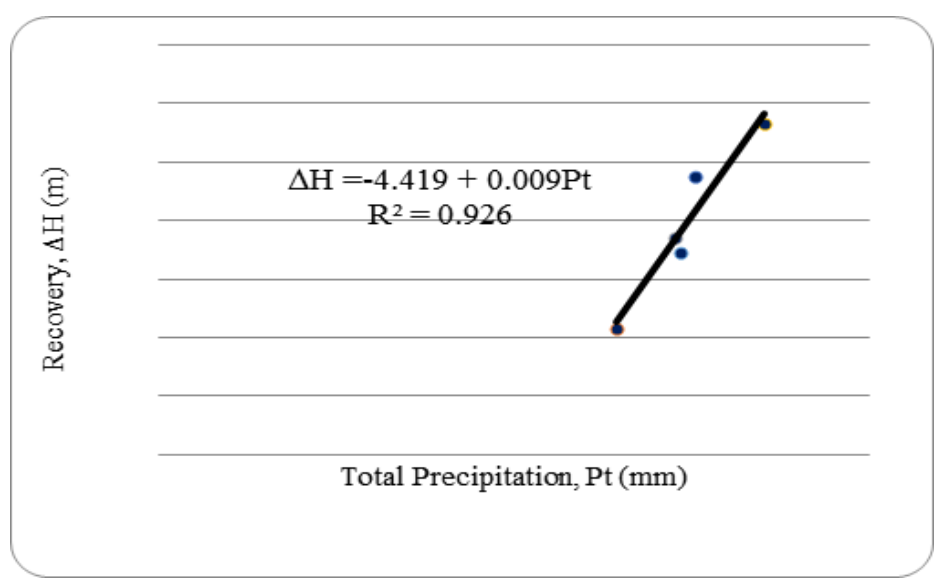

Figure 8. Total precipitation (GSMaP) in wet period - recovery of groundwater level relationship in Werdapura Observation Well

Table 5. Hydrologic characteristic of Werdapura Observation Well based on GSMaP data

\begin{tabular}{ccccc}
\hline & \multicolumn{2}{c}{ Wedarpura Observation Well } & \multicolumn{2}{c}{$\begin{array}{c}\text { Interception } \\
\mathrm{Pe}=490.78 \mathrm{~mm}\end{array}$} \\
\hline year & $\begin{array}{c}\text { Annual } \\
\text { Precipitation } \\
\mathrm{P}_{\mathrm{y}}(\mathrm{mm})\end{array}$ & $\begin{array}{c}\text { computed Total } \\
\text { Precipitation } \\
\mathrm{P}_{\mathrm{t}}=(\Delta \mathrm{H}+\mathrm{a}) / \mathrm{b}(\mathrm{mm})\end{array}$ & $\begin{array}{c}\text { Recovery } \\
\Delta \mathrm{H}(\mathrm{m})\end{array}$ & $\begin{array}{c}\text { Recharge } \\
\mathrm{P}_{\mathrm{s}}(\mathrm{mm}) \\
\left(\mathrm{P}_{\mathrm{s}}=\mathrm{P}_{\mathrm{tc}}-\mathrm{P}_{\mathrm{e}}\right)\end{array}$ \\
\hline 2005 & 857.290 & 682.11 & 1.72 & 191.33 \\
2006 & 738.023 & 609.89 & 1.07 & 119.11 \\
2007 & 877.878 & 696.56 & 1.85 & 205.78 \\
2008 & 922.411 & 804.33 & 2.82 & 313.56 \\
2009 & 862.732 & 754.33 & 2.37 & 263.56 \\
Average & 851.67 & 709.44 & & 218.67 \\
\hline
\end{tabular}

By using the method of calculation and similar analysis procedures for the precipitation of gauge data, GSMaP and groundwater level fluctuation data from observation wells, and then the recharge rate each of the observation wells is obtained. The calculation results can be seen in summary average recharge from precipitation Table 6 below.

Monthly average precipitation measured with GSMaP amounts was about 41 percent of the precipitation measured by rain gauge. The statistical relationship between the precipitation from GSMaP and rain gauge were revealed a strong correlation, the coefficient of determination was 0.82 , and the distribution patterns is similar, namely the rainy season occurs between the months of November April. While the dry season occurs between the months of July to August and punctuated by a transitional season this patterns is agree with monsoonal pattern according to As-syakur et al. (2013).

The recharge from precipitation events due to precipitation that occurs $1 \sim 2$ months earlier give the high correlation, and each of monitoring wells showed the highest coefficient of correlation values between $0.71 \sim 0.77$ this is mean that precipitation takes between 1 2 months to get into the saturated zone and recharging the ground water.

During the period of five years data analyzed there ware difference of volume of precipitation infiltrated into the groundwater this phenomena was occurred because of some factors; Soil type, land cover, topographic and climate. Other factors affecting recharge such as transmissivity, permeability and specific capacity of the aquifer layer. The annual recharge from precipitation in period of $2005 \sim 2009$ is averaging $655.33 \sim 659.33 \mathrm{~mm} /$ year or about $31.62 \sim 31.81$ percent/year of the average annual precipitation recording by rain gauge. Meanwhile by using GSMaP_MVK data the result of annual recharge from precipitation for the same period is averaging 218.67 219.78 
$\mathrm{mm} /$ year or about $25.68 \sim 25.81$ percent/year. This revealed an underestimate. It may cause of the global spatial resolution of GSMaP_MVK data.

The previous study two methods have been performed in the area of research. The amount of precipitation that falls and then seep into the ground can be calculated by considering the porosity and permeability of the rock cover, by ignoring evapotranspiration and surface runoff. Calculation of groundwater recharge by using this method the results are still rough, recharge rate obtained was $1438 \mathrm{~mm} / \mathrm{yr}$. Another way to know groundwater recharge is by calculating the amount of groundwater flow using Darcy formula, the previous study result is $492 \mathrm{~mm} / \mathrm{yr}$ (Lavalin International Inc., 1985).

If the value compared with the results of estimation performed in previous studies with different methods turned out to one another is not the same. Recharge value calculated by using precipitation recharge method is $1438 \mathrm{~mm}$ /year different with groundwater flow method is $492 \mathrm{~mm} /$ year. This is probably due to the number of evapotranspiration and surface runoff have not been included in the calculation. Recharge number as the results of calculations using the method of groundwater flow (darchi low) and the method of groundwater level fluctuation is not much different. Both calculation results are considered more acceptable, based on decree of the director general water resources number $71 / \mathrm{KPTS} / \mathrm{A} / 1985$. Therefore the amount of ground water recharge rate in Denpasar and the surrounding area is $218 \mathrm{~mm}-660 \mathrm{~mm}$ per year or about $26 \sim 32$ percent/year.

\section{Conclusions and Suggestions}

The conclusions are: (1) Monthly average precipitation measured with GSMaP amounts was about 41 percent of the precipitation measured by rain gauge. It was revealed underestimate. The statistical relationship between the precipitation from GSMaP and rain gauge were revealed a strong correlation, the coefficient of determination was 0.82 . The distribution patterns were similar. Wet season occurred from November to April, while the dry season occurred from July to August and punctuated by a transitional season, which was monsoonal precipitation patterns; (2) Groundwater recharge event due to precipitation that occurred 1 2 months earlier gave a strong correlation with groundwater level changes. The highest coefficient of correlation values were between 0.71 $\sim 0.77$ which means that precipitation took about $1 \sim 2$ months to recharge the groundwater; (3) Recharge rate of the aquifer calculated by using groundwater level fluctuation method was ranging from $218 \sim 220 \mathrm{~mm} /$ year or about 26 percent/year based on GSMaP data, and $650 \sim 660 \mathrm{~mm}$ per year or about 32 percent of the average annual precipitation measured by rain gauge. The recharge rate from GSMaP was revealed underestimate and it from rain gauge was more acceptable. The accuracy of the results also depends on groundwater level data base.

Suggestions of this research are: (1) Based on the results to estimate precipitation amounts and patterns is suggested to use data from rain gauge, while GSMaP can be used when density of rain gauge is low; (2) Groundwater exploitation should consider the negative impacts that may arise and need to preserve groundwater recharge areas such as land cover conservation and creating artificial recharge; (3) The future research on groundwater recharge is advised to use the data from the rain gauge and the groundwater level with a longer period of time.

\section{References}

As-syakur, A. R., Tanaka, T., Osawa, T., \& Mahendra, M. S. (2013). Indonesian rainfall variability observation using TRMM multi-satellite data. International journal of remote sensing, 34(21), 7723-7738.

Degallier, R. (1966). Interpretation de Courbes exponentielles de tarissement. Memories de AIH Beograd: pages $171-172$.

Hadiwidjojo, P. M. M., Samodra, H., \& Amin, T.C. (1998). Geological Map of the Bali sheet, Nusatenggara. Second Edition. Bandung-Indonesia: Geological Research and Development Center.

Korkmaz, N. (1988). The estimation of groundwater recharge from water level and precipitation data. Journal of Islamic Academy of Sciences, 1(2), 87-93. 
Lavalin International Inc. (1985). Southern Bali Groundwater Investigation. Volume 2. DenpasarIndonesia: Directorate General of Water Resources Development.

Meijerink, A. M. J. (1996). Remote sensing applications to hydrology: groundwater. Hydrological sciences journal, 41(4), 549-561.

Moon, S. K., Woo, N. C., \& Lee, K. S. (2004). Statistical analysis of hydrographs and water-table fluctuation to estimate groundwater recharge. Journal of Hydrology, 292(1), 198-209.

(C) 201x by the authors; licensee Udayana University, Indonesia. This article is an open access article distributed under the terms and conditions of the Creative Commons Attribution (CC-BY) license (http://creativecommons.org/licenses/by/4.0/). 